\title{
EFFECT OF DIETARY POLYUNSATURATED FATTY ACIDS AND ANTIOXIDANTS SUPPLEMENTATION ON PRODUCTIVE PERFORMANCE, IMMUNE RESPONSE AND BLOOD PARAMETERS OF BROILER CHICKENS
}

\author{
M.S. Elsharkawy ${ }^{\text {; }}$ I. El-Wardany ${ }^{2}$; S.A. Abdel-Fattah ${ }^{2}$; Laila D. Abd El-Samee ${ }^{1}$ and \\ Nafisa A. Abd El-Azeem ${ }^{1}$ \\ ${ }^{1}$ Department of Animal Production, National Research Centre, 33 Bohouthst., Dokki, Giza, Egypt. \\ ${ }^{2}$ Department of Poultry Production, Faculty of Agriculture, Ain Shams Univ., Shobra El-Kheima, \\ Cairo, Egypt.
}

\section{SUMMARY}

$\mathrm{T}$ his study conducted to investigate the effects of dietary linseed oil (LO) or fish oil (FO) and/or antioxidants on productive performance, immune response, carcass traits and blood parameters of broiler chickens. A total of 168 one-day-old, Cobb broiler chicks were obtained from a local commercial hatchery. The birds were randomly divided into seven groups with three replicates, eight chicks each. Birds of the seven groups were fed on iso-caloric and iso-nitrogenous diets containing the same ingredients (basal diet) except the source of oil and addition of antioxidants. The first group was fed on the basal diets containing $2 \%$ soya oil (control), the $2^{\text {nd }}, 3^{\text {rd }}$ and $4^{\text {th }}$ groups were given the basal diets containing $2 \% \mathrm{LO}, 2 \% \mathrm{LO}+200 \mathrm{mg}$ vitamin E (vit E) $/ \mathrm{kg}$ or $2 \% \mathrm{LO}+0.2 \%$ Sweet Chestnut Tannin (SCT), respectively. While the $5^{\text {th }}, 6^{\text {th }}$ and $7^{\text {th }}$ groups were offered the basal diet containing $2 \% \mathrm{FO}, 2 \% \mathrm{FO}+200 \mathrm{mg}$ vit $\mathrm{E} / \mathrm{kg}$ or $2 \% \mathrm{FO}+0.2 \% \mathrm{SCT}$, respectively. During the whole period, adding FO without or with antioxidants significantly $(\mathrm{p} \leq 0.05)$ increased live body weight, body weight gain compared to control. Feed intake was not significantly ( $>0.05)$ affected by the dietary treatments. All dietary treatments had $(\mathrm{p} \leq 0.05)$ lower feed conversion ratio than the control. Moreover, the best FCR were recorded for the FO $+0.2 \%$ SCT dietary group, followed by the $\mathrm{LO}+2 \% \mathrm{SCT}, \mathrm{FO}$ and $\mathrm{FO}+200 \mathrm{mg}$ vit $\mathrm{E} / \mathrm{kg}$ groups. No significant $(\mathrm{P} \geq$ $0.05)$ difference among treatments was observed in carcass traits of broilers. Inclusion of FO with or without antioxidants in broiler diets improved antibody titer against SRBCs in immune response $(\mathrm{p} \leq 0.05)$ compared to control. A significant decrease in plasma total lipid concentration was observed with all dietary treatments. The best HDL value were observed for the FO $+0.2 \%$ SCT dietary group, followed by the FO and FO +200 $\mathrm{mg}$ vit $\mathrm{E} / \mathrm{kg}$ groups. It could be concluded that the inclusion of $2 \% \mathrm{FO}$ and/or antioxidants of the broiler diets improved the productive performance, immune response and plasma lipid of broilers. Moreover, the addition of $2 \%$ fish oil with $0.2 \% \mathrm{SCT}$ as antioxidants recorded the best productive performance, immune response and plasma lipids of broilers.

Keywords: Broilers, polyunsaturated fatty acids, antioxidants, performance, immune response and plasma lipids.

\section{INTRODUCTION}

Several studies had been conducted to increase the content of polyunsaturated fatty acids (PUFAs) in chickens and eggs by using dietary fat sources such as natural oil containing PUFAs (Kim et al., 2007). The oil supplement in diets is a very important resource of either long chain omega-3 PUFAs, as in fish oil (FO) or as a form of its precursor fatty acid, $\alpha$-linolenic (ALA), as in linseed oil (LO). (Zelenka et al., 2006). The utilization of diets rich in omega-3 PUFAs, such as FO and LO, can affect blood serum metabolites, such as triglycerides and total cholesterol (Safamehr et al., 2008; Viveros et al., 2009 and Velasco et al., 2010). Diets rich in PUFAs, can reduce triacylglycerol synthesis and fatty acids in liver, decreasing the concentration of plasma triglycerides in the broilers (Sanz et al., 2000). Supplementation of dietary FO improved the immune system (Tobarek et al., 2002). From broilers health aspect, omega-3 PUFAs improve performance, lipid profile besides increasing in marketing weight (Al-Zuhairy and Alasadi, 2013 and Sahib, 2013).

Polyunsaturated fatty acids are prone to oxidation since they are the first targets for free radical strike at initiating peroxidation (Scislowski et al., 2005). PUFAs in poultry meat make it sensitive to oxidative 


\section{Elsharkawy et al}

changes affecting smell and taste (Lopez-Ferrer et al., 1999). Lipid oxidation is a major cause of meat quality deterioration which lowers the functional, sensory and nutritive values of meat products; and therefore, consumer's acceptability (Bou et al., 2004). The notable strategies for diminishing lipid oxidation of meat are by adding antioxidants to poultry diets. Currently, the interest in natural antioxidants has increased because they are considered to be safer than the synthetic antioxidants, and have greater application potential for consumers' acceptability, palatability, stability and shelf-life of meat products (Park and Kim, 2008).

Vit $\mathrm{E}$ is considered as a very potent antioxidant in biological systems and found to be beneficial in counteracting the adverse effect of oxidative stress (Panda and Cherian 2014). In addition, one of the primary functions of vit $\mathrm{E}$ is to maintain membrane integrity, which it does via preventing oxidation of PUFAs in membrane phospholipids (Gropper et al., 2009). Also vit.E is essential for such body functions as growth, immune function enhancement, tissue integrity, reproduction, disease prevention, and antioxidant function in biological systems (DalleZotte and Szendro, 2011).

Tannins are a heterogeneous group of phenolic polymers. According to their chemical structure, they can be divided into hydrolyzed tannins and condensed tannins. Hydrolysable tannins are multiple esters of gallic acid with glucose and products of their oxidative reactions. Altogether, tannins are reported to have various physiological effects like antioxidant and antiradical activity (Arapitsas et al. 2012). Sweet chestnut is an important source of hydrolyzed tannins "phenolic compounds" (Ribeiro et al., 2007). Many studies have been carried out examining the role of tannins in the prevention of lipid oxidation (Cherian et al., 2002; Schiavone et al., 2008; Wang et al., 2008; Liu et al., 2009).

Therefore, the current study aimed to study the effects of feed containing PUFAs and antioxidants on productive performance, immune response, carcass traits and blood parameters of broiler chickens.

\section{MATERIALS AND METHODS}

A total of 168 one-day-old, Cobb broiler chicks were obtained from a local commercial hatchery. The birds were randomly divided into seven groups with three replicates, eight chicks each. Birds of the seven groups were fed on isocaloric and isonitrogenous diets containing the same ingredients (basal diet) except the source of oil and the added antioxidants.The first group was fed on the basal diets containing $2 \%$ soy oil, the $2^{\text {nd }}, 3^{\text {rd }}$ and $4^{\text {th }}$ groups were given the basal diets containing $2 \%$ linseed oil (LO), $2 \% \mathrm{LO}+200 \mathrm{mg}$ vit $\mathrm{E} / \mathrm{kg}$ or $2 \% \mathrm{LO}+0.2 \%$ Sweet Chestnut Tannin (SCT). While the $5^{\text {th }}, 6^{\text {th }}$ and $7^{\text {th }}$ groups were offered the basal diet containing $2 \%$ fish oil (FO), $2 \% \mathrm{FO}+200 \mathrm{mg}$ vit E/ $\mathrm{kg}$ or $2 \% \mathrm{FO}+0.2 \%$ SCT. Chicks of all groups were fed starter diets from 1-14 day of age (DOA) and grower diets from15-35 DOA. Basal control diets were formulated according to the recommendation of the National Research Council (NRC, 1994). Feed and water were offered ad-libitum during the experimental period, which lasted for five weeks. The composition and calculated chemical analyses of the basal diets are presented in Table 1 .

Vitamin E supplied by Adisseo Inc. French, it contain 50\% $\alpha$-tocopherol. Sweet Chestnut Tannin (supplied by Silva Team, San Michele di Mondov, Italy) is extracted from chestnut wood by a heat and low-pressure treatment; only the water-soluble fraction is retained and subsequently dehydrated. The product is commercially available as a fine brown powder (92 to $95 \%$ dray matter) with a pure tannin content of $77 \%$ on a dray matter basis (Tabacco et al., 2006). Chemical composition of the SCT was as follows: $2.9 \%$ water, $77.8 \%$ tannin, $17.7 \%$ nontannin, $1.6 \%$ insoluble, $0.24 \%$ crude fiber and $1.7 \%$ ash, (pH 3.26, 10\% solution).

\section{Growth performance parameters:}

Live body weight (LBW) of each chicks and feed intake (FI) for each group were recorded during the experimental period. Body weight gain (BWG) and feed conversion ratio (FCR), (FI / BWG) were calculated.

\section{Carcass characteristics:}

At the end of the experimental period, (35 DOA) two birds per replicate (6birds/treatment) were randomly selected, weighed individually, sacrificed by severing the jugular vein, Feathers were removed manually. Giblets percentage was calculated by dividing the accumulative weight of liver, heart and gizzard by LBW. The empty eviscerated yield carcasses were weighed and dressing percentage calculated. Abdominal fat, breast, wings and femur were also recorded and calculated as a percentage of LBW. Weights of bursa of Fabricius, thymus and spleen were recorded; the relative weights (as a percentage of live body weight) of lymphoid organs were calculated. 


\section{Humoral Immune Response:}

At the $3^{\text {rd }}$ week of age, six broiler chicks from each treatment were intramuscularly injected with $0.5 \mathrm{ml}$ sheep red blood cells (SRBCs) suspension (0.05 ml packed SRBCs mixed with $0.95 \mathrm{ml}$ phosphate buffered saline. Seven days post ( $4^{\text {th }}$ week) SRBCs antigen challenge, blood samples were collected from wing vein centrifuged $(4000 \mathrm{rpm} / 5 \mathrm{~min})$, sera were decanted and stored frozen at $-20^{\circ} \mathrm{C}$ until used for determination of primary immune response. At the $4^{\text {th }}$ week of age, second injection was done for the same chicks in a similar manner, then blood samples were collected after seven days (after slaughtering) for the measurement of secondary immune response. The antibody production (Abs) was measured using microtitre plate U-shape of 96 wells according the method of Hitchner et al. (1980).

Table (1). Composition and calculated analyses of the basal diets.

\begin{tabular}{|c|c|c|}
\hline Ingredients (\%) & Starter & Grower \\
\hline Yellow corn & 54.7 & 63.1 \\
\hline Soybean meal $44 \%$ & 33.3 & 26 \\
\hline Corn gluten meal $62 \%$ & 6.1 & 5.2 \\
\hline Soy oil $*$ & 2 & 2 \\
\hline Di calcium phosphate & 1.8 & 1.68 \\
\hline Calcium carbonate & 1.3 & 1.2 \\
\hline Premix ** & 0.3 & 0.3 \\
\hline DL-methionine $99 \%$ & 0.12 & 0.08 \\
\hline L-lysine $\mathrm{HCl}$ & 0 & 0.09 \\
\hline Salt & 0.38 & 0.35 \\
\hline Total $(\%)$ & 100 & 100 \\
\hline \multicolumn{3}{|l|}{ Calculated analysis } \\
\hline $\mathrm{DM}$ & 83.3 & 84 \\
\hline $\mathrm{CP} \%$ & 23.1 & 20.03 \\
\hline ME (Kcal/ Kg) & 2996 & 3081 \\
\hline $\mathrm{CF} \%$ & 3.61 & 3.28 \\
\hline $\mathrm{EE} \%$ & 2.71 & 2.9 \\
\hline Calcium\% & 1.01 & 0.92 \\
\hline Av.Phosphorus \% & 0.46 & 0.43 \\
\hline Methionine $\%$ & 0.51 & 0.43 \\
\hline Methionine + Cystine $\%$ & 0.9 & 0.77 \\
\hline Lysine \% & 1.1 & 1.01 \\
\hline \multicolumn{3}{|c|}{ *soy oil was replaced by linseed oil in the experimental group 2, 3 and 4, and by fish oil in the experimental group } \\
\hline \multicolumn{3}{|c|}{$\begin{array}{l}\text { ** Each } 3 \mathrm{Kg} \text { contains: vit A } 12000.000 \mathrm{IU} \text {, vit D3 } 5000.000 \mathrm{IU} \text {, vit E } 60.000 \mathrm{mg} \text {, vit K3 } 3000 \mathrm{mg} \text {, vit B1 } 2000 \mathrm{mg} \text {, } \\
\text { vit B2 } 8000 \mathrm{mg} \text {, vit B6 } 4000 \mathrm{mg} \text {, vit B12 } 15 \mathrm{mg} \text {, Nicotinic acid } 50.000 \mathrm{mg} \text {, Biotin } 200 \mathrm{mg} \text {, Folic acid } 2000 \mathrm{mg} \text {, } \\
\text { Pantothenic acid } 12000 \mathrm{mg} \text {, Choline } 4000 \mathrm{mg} \text {, Manganese } 100.000 \mathrm{mg} \text {, Iron } 40.000 \mathrm{mg} \text {, Copper } 15000 \mathrm{mg} \text {, Iodine } \\
1000 \mathrm{mg} \text {, Selenium } 300 \mathrm{mg} \text {, Zinc } 100.000 \mathrm{mg} \text {. }\end{array}$} \\
\hline
\end{tabular}

\section{Plasma lipids parameters:}

At the end of the experimental period, blood samples (6 samples/ treatment) were collected in heparinzed tubes, centrifuged (4000 rpm) for 10 minutes and plasma was then decanted in Eppendorf tubes and stored at $-20^{\circ} \mathrm{C}$ until biochemical analysis. Plasma total lipids $(\mathrm{mg} / \mathrm{dl})$ were determined according to the method of (Knight et al., 1972).Triglyceride and cholesterol were determined according to Tietz (1995) and HDL- cholesterol was determined according to Burstein (1970). The concentration of LDL- cholesterol can be calculated according to Friedewald formula:

LDL $(\mathrm{mg} / \mathrm{dl})=$ Total cholesterol $-($ Triglycerides/5) - HDL- cholesterol (Friedewald, 1972).

\section{Statistical analysis:}

Data were subjected to the analysis of variance by using the General Linear Models Procedure (GLM) of the Statistical Analysis System (SAS, 1994). Differences among treatment means were detected using Duncan's multiple range test (Duncan, 1955). 


\section{Elsharkawy et al}

\section{RESULTS AND DISCUSSION}

\section{Productive performance:}

Results concerning the productive performance of broiler chickens fed different sources of oils and antioxidants are presented in Table 2. Initial live body weight (LBW) of broiler chicks was similar for all treatments. Adding fish oil (FO) without or with antioxidants and linseed oil (LO) plus $0.2 \%$ Sweet Chestnut Tannin (SCT) significantly $(\mathrm{p} \leq 0.05)$ increased LBW compared to control at 21 and $35 \mathrm{~d}$ of age (DOA).

Table (2). Effect of dietary supplementation with different sources of oils and antioxidants on productive performance of broiler chicks.

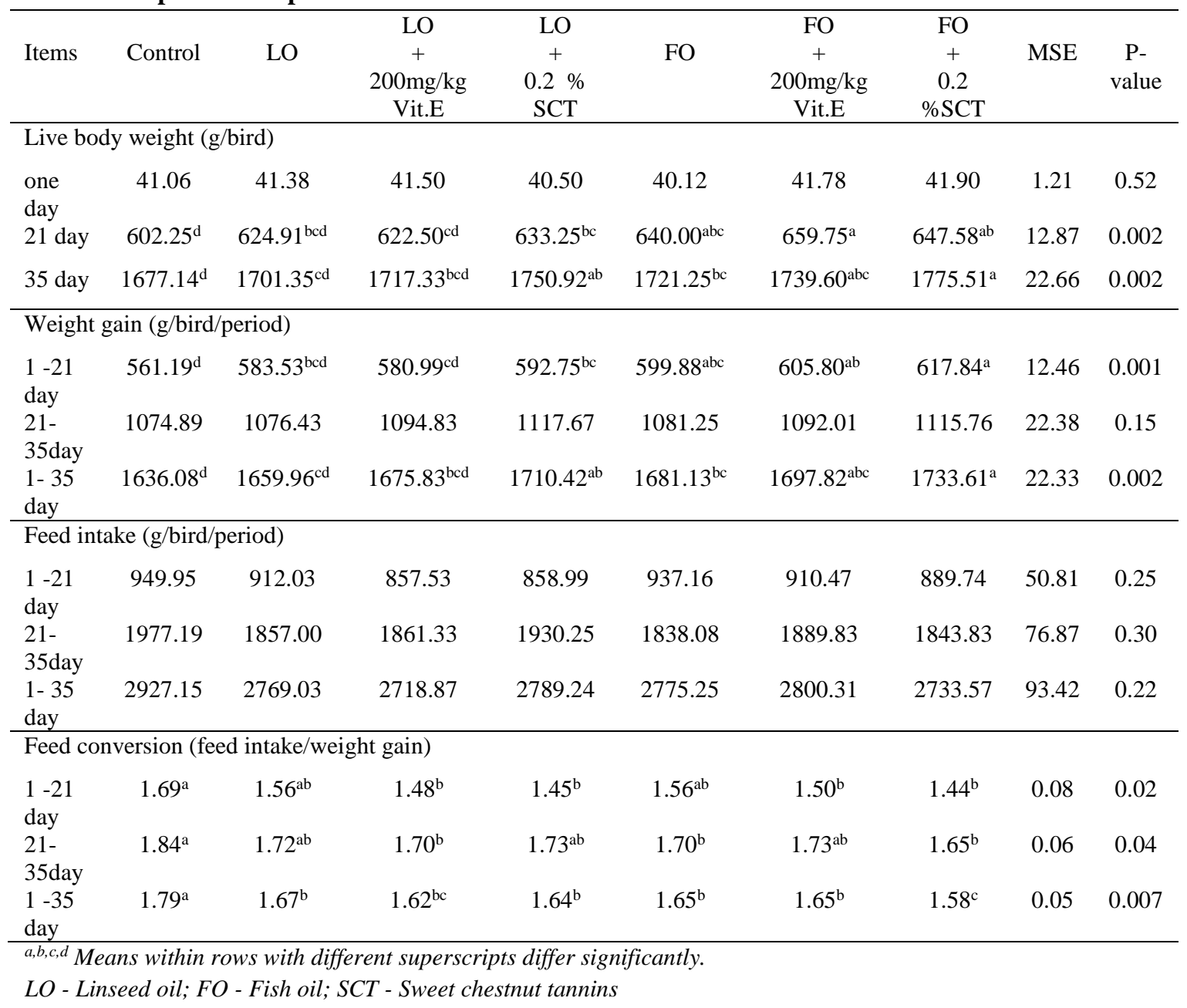

Body weight gain $(\mathrm{BWG})$ was significantly $(\mathrm{p} \leq 0.05)$ increased by LO $+0.2 \% \mathrm{SCT}, \mathrm{FO}, \mathrm{FO}+200$ $\mathrm{mg}$ vit $\mathrm{E} / \mathrm{kg}$ and $\mathrm{FO}+0.2 \% \mathrm{SCT}$ for broiler diets compared to control during the experimental period from 1-21 and 1-35 DOA. While during 21-35 d of age, BWG was not affected ( $>$ > 0.05) with the tested treatments. At all the experimental period, feed intake (FI) was not significantly (p>0.05) affected by the dietary treatments.

Inclusion of LO or FO with antioxidants in broiler diets reduced $(p \leq 0.05)$ feed conversion ratio (FCR) than the control during the period from 1 - 21 DOA, the lowest value was recorded for FO $+0.2 \%$ SCT. Birds fed FO + 0.2\% SCT had the best FCR compared to other dietary treatment at 21-35 DOA. During the whole period, the all-dietary treatments had significantly $(p \leq 0.05)$ higher FCR than the control. Moreover, the best FCR were recorded for the FO + 0.2\% SCT dietary group, followed by the $\mathrm{LO}+2 \% \mathrm{SCT}, \mathrm{FO}$ and $\mathrm{FO}+200 \mathrm{mg}$ vit $\mathrm{E} / \mathrm{kg}$ groups .

The enhancement of productive performance by feeding broilers FO may be due to increase diet digestibility, which stimulate growth and feed efficiency (Saleh et al., 2009; Chekani-Azar, 2010 and 
Hosseini 2011). Because of activation of bile, which lead to increase digestion of fats in the intestine, and increase efficiency of digestion and absorption of diets in intestine lead to more useful from the diet (AlZuhairy and Alasadi, 2013; Al-Zuhairy and Jameel, 2014 and Jameel and Sahib, 2014). Omega-3 long chain polyunsaturated fatty acids (PUFAs) in FO has been shown, to reduce the catabolic response induced by immune stimulation and may be effective in promoting growth (Rymer and Givens, 2005).

The improvement of productive performance by feeding broilers FO and antioxidants may be attributed to highly susceptible to oxidative process of oils rich in long chain omega-3 PUFAs like FO and vit $\mathrm{E}$ is a good defender against lipid oxidation (Surai and Spark, 2000). Cortinas et al. (2005) observed improvement in oxidation stability of chicken muscles fed PUFAs together with $200 \mathrm{or} 400 \mathrm{mg}$ vit E/ kg diet. Rocha et al. (2012) reported that supplemental levels of vit E might act as an antioxidant by inhibiting lipid peroxidation of the membrane, maintaining its integrity and the gut health of turkey fed oxidized oil. The DPPH radical scavenging activity of gallic acid showed 4-folds higher than that of $\alpha$ tocopherol (Jang et al., 2009). Chestnut tannins (source of gallic acid) limiting the development of some unfavorable bacteria, improving the health of the broiler and consequently stimulating growth performance (Schiavone et al., 2008). Liu et al. (2009) showed that chestnut tannins significantly enhanced the activity of $\alpha$-amylase in rabbit small intestinal.

The results are in agreement with Das et al. (2014) who found that the highest cumulative BWG in the $2.5 \%$ FO-receiving group than $2.5 \%$ soybean oil-receiving group. Safamehr et al. (2008) and Hosseini and Bahrami (2011) showed that the levels of $2 \%$ FO had best significant effects on broiler productive performance. Dietary FO at 1.5, 3 and $4.5 \%$ levels significantly improved performance compared to control treatment. Chashnidel et al. (2010). Saleh et al. (2009); Chekani-Azar (2010) and Hosseini (2011) they reported that highest final LBW, highest daily BWG and the best FCR in broilers were recorded for the $1.5 \%$ FO dietary group followed by the $3 \%$ FO group.

Chae et al., (2006); Koreleski and Swiatkiewicz (2006) and Rebole et al. (2006) reported that the broilers fed $200 \mathrm{mg}$ vit.E/ kg had the largest BWG and the best FCR. Furthermore, Starcevic et al. (2014) reported that the inclusion of phenolic compounds enhanced growth performance in broilers. Gai et al. (2010) reported that feed conversion efficiency was increased in broilers according to dietary tannin level, up to $15 \mathrm{~g} / \mathrm{Kg}$ diet. Schiavone et al. (2007) reported that the inclusion of SCT at $0.20 \%$ in broilers had a significant influences on LBW, and BWG and a favourable influence on FCR in comparison with the other three groups $(0 \%, 0.15 \%$ and $0.25 \%$ SCT). Schiavone et al. (2008) reported that the use of up to $0.20 \%$ SCT had a positive influence on growth performance but, the inclusion of more than $0.20 \%$ SCT led to undesirable effects as all the measured parameters were the lowest in chick fed $0.25 \%$ chestnut tannin added diet.

\section{Carcass traits:}

The effect of dietary oils and antioxidants supplementation on carcass traits are shown in Table 3 . No significant $(\mathrm{P} \geq 0.05)$ difference among treatments was observed in carcass traits (carcass $\%$, liver $\%$, heart $\%$, gizzard $\%$, abdominal fat $\%$, breast $\%$, wings $\%$ and femur $\%$ ) of broilers.

Table (3). Effect of dietary supplementation with different sources of oils and antioxidants on carcass traits of broiler chicks.

\begin{tabular}{|c|c|c|c|c|c|c|c|c|c|}
\hline Items & Control & $\mathrm{LO}$ & $\begin{array}{c}\text { LO } \\
+ \\
200 \mathrm{mg} / \mathrm{kg} \\
\text { Vit.E }\end{array}$ & $\begin{array}{c}\text { LO } \\
+ \\
0.2 \% \\
\text { SCT }\end{array}$ & $\mathrm{FO}$ & $\begin{array}{c}\text { FO } \\
+ \\
200 \mathrm{mg} / \mathrm{kg} \\
\text { Vit.E }\end{array}$ & $\begin{array}{c}\text { FO } \\
+ \\
0.2 \% \\
\text { SCT }\end{array}$ & MSE & $\begin{array}{c}\mathrm{P}- \\
\text { value }\end{array}$ \\
\hline Carcass, $\%$ & 71.06 & 71.2 & 71.59 & 71.36 & 72.12 & 71.75 & 72.58 & 1.59 & 0.66 \\
\hline Liver, \% & 2.86 & 2.72 & 2.71 & 2.45 & 2.69 & 2.42 & 2.43 & 0.34 & 0.17 \\
\hline Heart, \% & 0.58 & 0.57 & 0.53 & 0.55 & 0.56 & 0.59 & 0.58 & 0.09 & 0.94 \\
\hline Gizzard, \% & 1.81 & 1.68 & 1.55 & 1.67 & 1.49 & 1.53 & 1.47 & 0.25 & 0.20 \\
\hline Giblets, \% & 5.25 & 4.97 & 4.79 & 4.67 & 4.74 & 4.53 & 4.47 & 0.48 & 0.12 \\
\hline $\begin{array}{l}\text { Abdominal fat, } \\
\%\end{array}$ & 1.95 & 1.89 & 1.99 & 1.62 & 1.45 & 1.58 & 1.50 & 0.40 & 0.09 \\
\hline Breast, \% & 24.16 & 24.37 & 25.08 & 24.8 & 24.5 & 25.09 & 25.14 & 0.90 & 0.36 \\
\hline Wings, \% & 7.05 & 6.88 & 6.70 & 6.73 & 7.13 & 6.57 & 6.3 & 0.52 & 0.12 \\
\hline Femur, \% & 22.17 & 22.82 & 23.03 & 22.97 & 22.95 & 23.44 & 23.7 & 0.85 & 0.09 \\
\hline
\end{tabular}

LO - Linseed oil; FO - Fish oil; SCT - Sweet chestnut tannins

Similar results were also obtained with Das et al. (2014) who showed that no significant differences on all carcass parameters and dressed yield the in the $2.5 \%$ FO-receiving group than $2.5 \%$ soybean oil- 


\section{Elsharkawy et al}

receiving group. Safamehr et al. (2008) found that fed male broiler 2\% and 3\% FO had no significant effects on weight of carcass yield, abdominal fat, thighs, breast, liver, gizzard, and heart among the treatment. Chekani-Azar et al. (2010) observed that carcass traits and in other parts of carcass, such as breast, thigh, liver, gizzard and heart and also, the amount of abdominal fat did not showed significant elevated when levels of dietary fish oil were increased $(0,1.5,3$, or $6 \%)$ in broiler diets. Also, Chashnidel et al. (2010) found that no significant differences on percent of carcass to live body weight and abdominal fat percentage to carcass weight in diet contained FO up to $4.5 \%$. Inclusion of vit $\mathrm{E}$ in the diets did not significantly influence the proportions of various carcass organs of the rabbits (Eiben et al., 2011 and Ebeid et al., 2013). No significant effects on carcass weight and liver, heart, breast, thigh and wing yields in broilers given LO compared to other lipid sources (Qi et al., 2010).

\section{Immunological parameters:}

The effects of dietary oils and antioxidants supplementation on immune response are shown in Table 4. Inclusion of FO with or without antioxidants in broiler diets improved antibody titer against sheep red blood cells (SRBCs) in primary immune response ( $\mathrm{p} \leq 0.05)$ compared control. Broiler fed $\mathrm{LO}+0.2 \%$ $\mathrm{SCT}, \mathrm{FO}, \mathrm{FO}+200 \mathrm{mg}$ vit $\mathrm{E} / \mathrm{kg}$ and $\mathrm{FO}+0.2 \% \mathrm{SCT}$ and diets had significantly increased antibody titer against SRBCs in secondary immune response compared to other treatments. No significant $(\mathrm{P} \geq 0.05)$ difference among treatments was observed in Thymus \% and Spleen \%. The addition of FO + SCT to broiler diets significantly $(\mathrm{p} \leq 0.05)$ increased bursa $\%$ compared to other treatments.

Table (4). Effect of dietary supplementation with different sources of oils and antioxidants on immunological parameters of broiler chicks

\begin{tabular}{|c|c|c|c|c|c|c|c|c|c|}
\hline $\begin{array}{l}\text { SRBCs } \\
\text { antibody titer } \\
(1 / \log 2) \text { titre }\end{array}$ & Control & $\mathrm{LO}$ & $\begin{array}{c}\text { LO } \\
+ \\
200 \mathrm{mg} / \mathrm{kg} \\
\text { Vit.E }\end{array}$ & $\begin{array}{c}\text { LO } \\
+ \\
0.2 \% \\
\text { SCT } \\
\end{array}$ & $\mathrm{FO}$ & $\begin{array}{c}\text { FO } \\
+ \\
200 \mathrm{mg} / \mathrm{kg} \\
\text { Vit.E }\end{array}$ & $\begin{array}{c}\text { FO } \\
+ \\
0.2 \% \\
\text { SCT } \\
\end{array}$ & MSE & $\begin{array}{c}\mathrm{P}- \\
\text { value }\end{array}$ \\
\hline $\begin{array}{l}\text { Primary }\left(4^{\text {th }}\right. \\
\text { wk) } \\
\text { Secondary } \\
\left(5^{\text {th }} w k\right)\end{array}$ & $5.00^{c}$ & $80 b^{c}$ & $6.00^{\mathrm{bc}}$ & $6.40^{\mathrm{b}}$ & $6.60^{\mathrm{b}}$ & $8.20^{\mathrm{a}}$ & $4.80^{\mathrm{a}}$ & 0.775 & $<.0001$ \\
\hline \multicolumn{10}{|c|}{ Lymphoid organs , \% } \\
\hline $\begin{array}{l}\text { Bursa, \% } \\
\text { Thymus, \% } \\
\text { Spleen, \% }\end{array}$ & $\begin{array}{c}0.207^{\mathrm{cb}} \\
0.323 \\
0.107\end{array}$ & $\begin{array}{l}0.215^{\mathrm{b}} \\
0.363 \\
0.113\end{array}$ & $\begin{array}{c}0.220^{\mathrm{b}} \\
0.358 \\
0.112\end{array}$ & $\begin{array}{l}0.218^{b} \\
0.357 \\
0.122\end{array}$ & $\begin{array}{l}0.220^{\mathrm{b}} \\
0.325 \\
0.103\end{array}$ & $\begin{array}{l}0.225^{\mathrm{b}} \\
0.348 \\
0.118\end{array}$ & $\begin{array}{l}0.278^{\mathrm{a}} \\
0.387 \\
0.128\end{array}$ & $\begin{array}{l}0.038 \\
0.049 \\
0.023\end{array}$ & $\begin{array}{l}0.04 \\
0.32 \\
0.55\end{array}$ \\
\hline
\end{tabular}

a,b,c,d Means within rows with different superscripts differ significantly.

LO - Linseed oil; FO - Fish oil; SCT - Sweet chestnut tannins; SRBCs - Sheep red blood cells

Supplementation of dietary FO improved the immune system (Tobarek et al., 2002), these results could be due to omega-3 which considered to be a substrate for the generation of prostaglandin, leukotriene and interleukin levels (Kidd, 2004). Also the length and degree of saturation of the specific omega-3 PUFAs have a major impact on the effects of dietary supplementation on immune function (Wall et al., 2010). Chekani-Azar (2010) found that the chickens fed FO $(0,1.5,3$, or $6 \%)$ rich in omega- 3 fatty acids showed an increase in humoral immune activity in response to the injection of SRBCs, the amount and type of PUFAs released in response to inflammatory stimuli depends on the cell membrane phospholipid fatty acid content. This is similar to Hosseini and Bahrami (2011) they indicated that the highest response to primary and secondary injections of SRBCs was observed in $4 \%$ FO group, followed by $2 \% \mathrm{FO}$ group compared to $0 \%$ and $1 \% \mathrm{FO}$ groups.

A significant increase in humoral immune responses against SRBCs when chickens were provided with higher concentrations of dietary $\alpha$-tocopherol (200-300 mg/ kg) (Boa-Amponsem et al., 2006). Because of the antioxidant effect of vit $\mathrm{E}$ for protect from long chain omega-3 PUFAs of high susceptible to lipid oxidation, can be help for a appropriate depot of Eicosapentaenoic (EPA) and docosahexaenoic (DHA) fatty acids in body by direct transfer from diet or liver conversion and therefore, a higher immune system response of body will actually achieve against diseases types by lipid defense of broiler diet.(Sijben et al. 2002 and Jeun-Horng et al. 2002). In addition, dietary vit E supplementation at 110 or $220 \mathrm{mg} / \mathrm{kg}$ of feed enhanced phagocytic activity of macrophages toward opsonized SRBCs (Konjufca et al., 2004). Singh et al. (2006) reported that chicks receiving supplements of $200 \mathrm{mg}$ vit E/ kg produced significantly higher antibody titres. This was associated with an increased serum concentration of total immunoglobulin and circulatory immune complexes. Moreover, Ebeid et al. (2013) reported that dietary 
vit E caused an improvement in the antibody titers against SRBCs of growing rabbits. Maroufyan et al. (2012) reported that there was no effect of dietary fats on the bursa of Fabricius weight. The increase of bursa \% may be attributed to added antioxidants in broilers diets. The chicks given $200 \mathrm{mg}$ vit E/ kg had significantly heavier bursa (Singh et al., 2006).

\section{Plasma lipids:}

Results concerning the plasma lipid concentration of broiler chickens fed different sources of oils and antioxidants are presented in Table 5. Significant decrease in plasma total lipid and total cholesterol concentration were observed with all dietary treatments. The lowest plasma total lipid and total cholesterol concentration were recorded for broilers group fed FO $+0.2 \% \mathrm{SCT}$. There was no significant difference in plasma triglyceride concentration of broilers chicks among tested treatments.

High-density lipoprotein (HDL) was significantly increased with inclusion of FO (alone or with antioxidants) and LO plus $0.2 \%$ SCT in broiler diets compared with the other treatments. While, plasma low-density lipoprotein (LDL) was significantly lowered with tested treatments compared to control in broilers. The best LDL value were observed for the FO $+0.2 \%$ SCT dietary group, followed by the FO and $\mathrm{FO}+200 \mathrm{mg}$ vit $\mathrm{E} / \mathrm{kg}$ groups.

Table (5). Effect of dietary supplementation with different sources of oils and antioxidants on plasma lipids of broiler chicks.

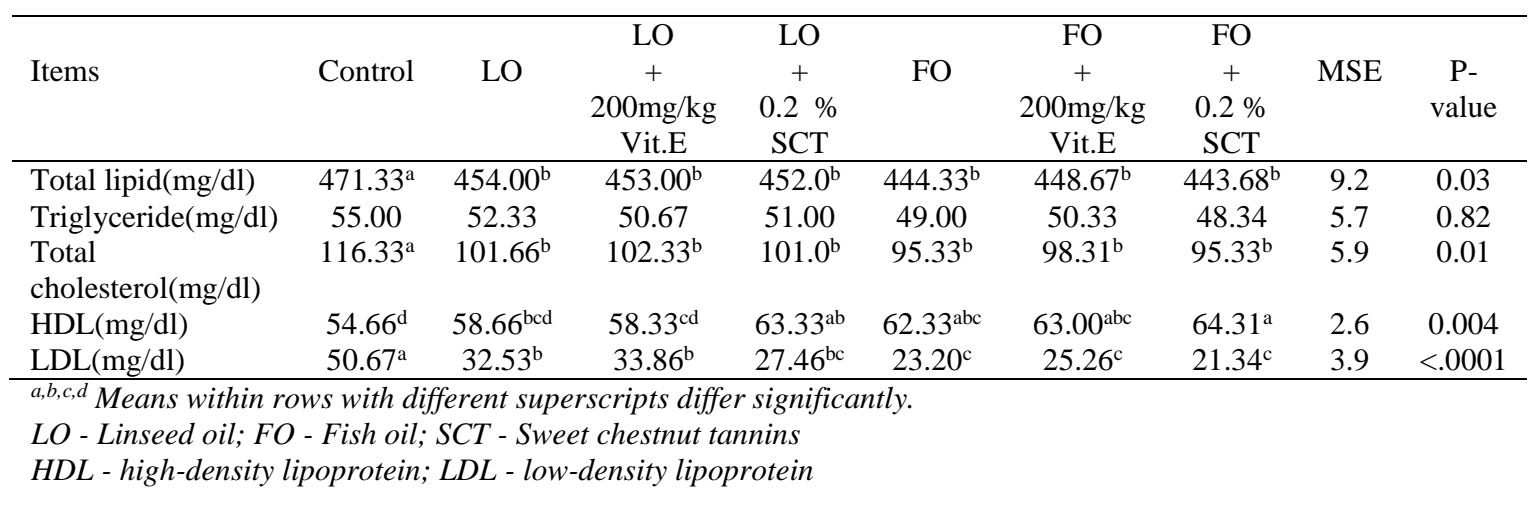

The inclusion of FO in the broilers diet improved plasma lipoprotein concentrations may be due to the reduction of hepatic synthesis and secretion of triglycerides by decreasing activity of synthetic enzymes, increasing proximal beta oxidation, increasing in the expression of hepatic receptor for LDL which caused by longer chain omega-3 PUFAs such as EPA and DHA (Belzung et al., 1993 and Schumann et al., 2000).

The present results are accordance with Saleh et al. (2009) who found that broilers fed FO (0.0\%, $1.5 \%, 3.0 \%$ and $6 \%$ ) had lower levels of serum cholesterol compared with the control. Also, Safamehr et al. (2008) showed that increasing different levels of FO 2\% and 3\% indicated highest HDL and lowest LDL concentrations in serum than control treatment. Chashnidel et al. (2010) found that serum cholesterol and LDL concentrations were significantly reduced by FO as dietary supplements at levels (.5, 3 and $4.5 \%$ than the control diet, but serum HDL concentrations were significantly increased by using diets containing FO. In addition, Hosseini and Bahrami (2011) who used the FO as dietary supplements at levels $(0,1,2$, or $4 \%)$ and indicated that the serum cholesterol and triglyceride levels significantly decreased in the FO groups at the 42 DOA. The addition of FO with different levels 1.5, 3, or $6 \%$ significantly decreased in serum cholesterol levels than the control (Hosseini, 2011). Starcevic et al. (2014) reported that the inclusion of phenolic compounds decreased cholesterol value.

\section{CONCLUSION}

It could be concluded that the inclusion of $2 \% \mathrm{FO}$ and/or antioxidants of the broiler diets improved the productive performance, humoral immune response and plasma lipid of broilers. Moreover, the addition of $2 \%$ fish oil with $0.2 \%$ SCT as antioxidants recorded the best productive performance, immune response and plasma lipids of broilers. 


\section{Elsharkawy et al}

\section{REFERENCES}

Al-zuhairy, M. A. and Y. j. Alasadi (2013). Effect of in ovoinjection with Newcastle disease vaccine, multivitaminsAD3E, and omega-3 on performance and immuneresponse of broiler. Int. J. of adva. Biolog. Res., 3: 208-211.

Al-zuhairy, M. A. and Y. J. Jameel (2014). Effect of ND Vaccine, Multivitamins AD3E, and Omega-3 on Performance and Immune Response of Broilers. MRSVA. 3: 42-50.

Arapitsas, P. (2012). Hydrolyzable tannin analysis in food. Food Chem., 135: 1708-1717.

Belzung F.; T. Raclot and R. Groscolas (1993). Fish oil n-3 fatty Acids selectively limit the hypertrophy of abdominal fat depots in growing rats fed high-fat diets. Am. J. Physiol. 264: 1111-1118.

Boa-Amponsem, K.; M. Picard; M.E. Blair; B. MELDRUM and P.B. Siegel (2006). Memory antibody responses of broiler and Leghorn chickens as influenced by dietary vitamin $\mathrm{E}$ and route of sheep red blood cell administration. Poult. Sci., 85: 173-177.

Bou, R.; F.Guardiola; A. Tres; A.C. Barroeta and R. Codony (2004). Effect of dietary fish oil, $\alpha-$ tocopheryl acetate, and zinc supplementation on the compositionand consumer acceptability of chicken meat. Poult. Sci. 83: 282-292.

Burstein, M.; H.R. Selvenick and R.J. Mortin (1970). Estimation of LDL/HDL cholesterol in serum. Lipid Res., 11: 583.

Chae, B.J.; J.D. Lohakare and J.Y. Choi (2006). Effect of incremental level of $\alpha$ - tocopheryl acetate on performance nutrient digestibility and meat quality of commercial broilers. Asian-Aus. J. of Anim. Sci., 19: 203-203.

Chashnidel, Y.; H. Moravej; A. Towhidi; F. Asadi, and S. Zeinodini (2010). Influence of different levels of n-3 supplemented (fish oil) diet on performance, carcass quality and fat status in broilers. Afr. J. of Bio, 9: 687-691.

Chekani-Azar S.; N. Hosseini-Mansoub; F.Y. Bahrami Ahadi and A. Lotfi (2010). Dietary fish oil improves performance and carcass characterizes of broilers immunized with sheep Erythrocytes. Int. J. Aca. Res., 2, 94.

Chen.W.; R. Zhao; B.X. Yan; J.S. Zhang; Y.Q. Huang; Z.X. Wang and Y.M. Guo (2014). Effects of the replacement of corn oil with linseed oil on fatty acid composition and the expression of lipogenic genes in broiler chickens. Czech J. Anim. Sci., 59: 353-364.

Cherian, G.; R. K. Selvaraj; M. P. Goeger and P. A. Stitt (2002). Muscle fatty acid composition and thiobarbituric acid-reactive substances of broilers fed different cultivars of sorghum. Poult. Sci. 81: 1415-1420.

Cortinas, L.; A. Barroeta; C. Villaverde; J. F. Guardiola and M. D. Baucells (2005). Influence of the dietary polyunsaturated level on chicken meat quality: lipid oxidation. Poult. Sci., 84: 48-55.

Dalle Zotte, A; and Z. Szendro (2011).The role of rabbit meat as functional food. Meat Sci., 88: 319-331.

Das G.B.; M.E. Hossain and M.A. Akbar (2014). Effects of different oils on productive performance of broiler. Iranian J. Appl. Anim. Sci., 4: 111-116.

Duncan, D. B. (1955). Multiple range and multiple F tests. Biometrics. 11:1- 42.

Ebeid T.A.; H. Zeweil; M.M. Basyony; W.M. Dosoky H. Badry (2013). Fortification of rabbit diets with vitamin $\mathrm{E}$ or selenium affects growth performance, lipid peroxidation, oxidative status and immune response in growing rabbits. Livestock Sci., 155: 323-331.

Eiben, C.S.; B. Vegi; G.Y. Virag; K. Godor-Surmann; K. Kustos; A. Maro; M. Odermatt; E. Zsedely; T. Toth; J. Schmidt and H. Febel (2011). Effect of level and source of vitamin E addition of a diet enriched with sun flower and linseed oils on growth and slaughter traits of rabbits. Livest.Sci. 139: 196-205.

Friedewald, W.T. (1972). Estimation of the concentration of low-density lipoprotein cholesterol in plasma, without use of the preparative ultracentrifuge. Clin. Chem., 14, 449.

Gai, F.; L. Gasco, A. Schiavone and I. Zoccarato (2010). Chapter 12. Nutritional effects of chestnut tannins in poultry and rabbit. Chapter 12. In: G.K. Petridis (ed.). Tannins: Types, Foods Containing and Nutrition. Nova Publishing, Hauppauge, N.Y. p. 297-306.

Gropper, S.S.; J.L. Smith and J.L. Groff (2009). Advanced Nutrition and Human Metabolism, $5^{\text {th }}$ ed. (Belmont, USA, Wadsworth Cengage Learning).

Hitchner, S. B.; C. H. Domrmuth; H. G. Purchase and J. E. Williams (1980). Isolation and identification of avian pathologists. Creative printing company Inc. Endwell. NY.

Hosseini-Mansoub, N. (2011). Effect of fish oil on performance and blood indices in broiler chicks immunized with sheep erythrocytes. Adv. Environ. Biol., 5: 1166-1171. 
Hosseini-Mansoub, N. and Bahrami, Y. (2011). Influence of dietary fish oil supplementation on humoral immune response and some selected biochemical parameters of broiler chickens. J. of Agrobio., 28: $67-77$

Jameel, Y.J. and A.M. Sahib (2014). Study of some blood parameters of broilers fed on ration containing fish oil. J. of Biol., Agri. and Healthcare, 4:67-71.

Jang, A.; N.Y. Lee; B.D. Lee; T.H. Kim; J.H. Son; B.J. and C. Jo (2009). Biological functions of a synthetic compound, octadeca-9, 12-dienyl-3, 4, 5 hydroxybenzoate, from gallic acid- linoleic acid ester. Food Chem., 112: 369-373.

Jeun-Horng Lin; Lin Yuan-Hui and Kuo Chun-Chin (2002). Effect of dietary fish oil on fatty acid composition, lipid oxidation and sensory property of chicken frankfurters during storage. Meat Sci. 60: $161-167$.

Kidd, M. T. (2004). Nutritional modulation ofimmune function in broiler. Poult. Sci., 83: 650-657.

Kim, J. H.; J. Hwangbo; N. J. Choi; H. G. Park; D. H. Yoon and E. W. Park (2007). Effect of dietary supplementation with conjugated linoleic acid, with oleic, linoleic, or linolenic acid on egg quality characteristics and fat accumulation in the egg yolk. Poult. Sci., 86: 1180-1186.

Knight, J.A.; S. Anderson and J. M. Rawle (1972). Chemical base of the sulfo-phospho-vanilin reaction for estimation total serum lipids. Clin. Chem., 18:199-208.

Konjufca, V. K.; W. G. Bottje; T. K. Bersi and G. F. Erf (2004). Influence of dietary vitamin E on phagocytic functions of macrophages in broilers. Poult. Sci. 83: 1530-1534.

Koreleski, J.; S. Swiatkiewicz (2006). The influence of dietary fish oil and vitamin E on the fatty acid profile and oxidative stability of frozen stored breast meat. J. Anim. Feed Sci. 15: 631-640.

Liu H.W.; F. Gai; L. Gasco; A. Brugiapaglia; C. Lussiana; K.J. Guo; J.M. Tong and I. Zoccarato (2009). Effects of chestnut tannins on carcass characteristics, meat quality, lipid oxidation and fatty acid composition of rabbits. Meat Sci., 83: 678-683.

Lopez-Ferrer, S.; M.D. Baucells; A.C. Barroeta and M.A. Grashorn (1999). n-3 Enrichment of chicken meat using fish oil: Alternative substitution with rapeseed and linseed oils. Poult. Sci., 78: 356-365.

Maroufyan Elham; Azhar Kasim; Mahdi Ebrahimi; Tech Chwen Loh; Mohd Hair Bejo; Hailemariam Zerihun; Fatemeh Hosseni; Yong Meng Goh and Abdoreza Soleimani Farjam (2012). Omega-3 polyunsaturated fatty acids enrichment alters performance and immune response in infectious bursal disease challenged broilers. Lip. In Health and Dise., 11:15.

NRC. (1994). Nutrient requirements of poultry. $9^{\text {th }}$ rev. ed. Natl. Acad. Press. Washington, DC.

Panda, A. K. and G. Cherian (2014). Role of Vitamin E in Counteracting Oxidative Stress in Poultry. J. Poult. Sci., 51: 109-117.

Park, C. I. and Y. J. Kim (2008). Effects of dietary mugwort powder on the VBN, TBARS, and fatty acid composition of chicken meat during refrigerated storage. Korean J. of Food Sci. of Anim. Resources, 28: 505-511.

Qi K. K.; J. L. Chen; G. P. Zhao; M. Q. Zheng and J. Wen (2010). Effect of dietary omega6/omega3 on growth performance, carcass traits, meat quality and fatty acid profiles of Beijing- you chicken. J. of Anim. Phys. and Anim. Nutri., 94: 474-485.

Rebole, A.; M.L. Rodriguez; L.T. Ortiz; C. Alzueta; C. Centeno; A. Viveros; A. Branes and I. Arija (2006). Effect of dietary high-oleic acid sunflower seed, plam oil and vitamin E supplementation on broiler performance, fatty acid composition and oxidation susceptibility of meat. British Poult. Sci., 47: 581-591.

Ribeiro, S. M.; J. H. Queiroz; M. E. Queiroz; F. M. Campos and H. M. Santana (2007). Antioxidant in Mango (Mangifera indica L.) pulp. Plant. Food Hum. Nutr. 62: 13-17.

Rocha, C.; A. Maiorka; F. L. de Paula Valle; V. Gonsales Schramm; A. L. Angeli and A. V. Fischer da Silva (2012). The effect of soybean oil quality and vitamin E supplementation on turkey diet nutrition. J. Appl. Poult. Res., 21: 318-324.

Rymer, C. and D.I. Givens (2005). N-3 fatty acidenrichment of edible tissue of poultry: Areview. Lipids, 40: $121-130$. 


\section{Elsharkawy et al}

Safamehr, A.; N. Aghaei and Y. Mehmannavaz (2008). The influence of different levels of dietary fish oil on the performance carcass traits and blood parameters of broiler chickens. Research J. of Biolog.Sci., 3: $1202-1207$.

Sahib, A. M. (2013) Effect of ration supplementation withdifferent levels of fish oil and flaxseed oil on productive traitsin broilers.M.Sc. Thesis in science of public health.Collegeof Veterinary Medicine.University of Baghdad. Iraq.

Saleh, H.; S.H. Rahimi and M.A. KarimiTorshizi (2009). The effect of diet that contained fish oil on performance, serum parameters, the immune system and the fatty acid composition of meat in broilers. Int. J. Vet. Res. 3: 69-75.

Sanze, M.; C.J. Lopez-bote; D. Menoyo and J.M. Bautista (2000). Abdominal fat deposition and fatty acid synthesis are lower and $\beta$-oxidation is higher in broiler chickens fed diets containing unsaturated rather than saturated fat. J. of Nutri., 130: 3034-3037.

SAS (1994). SAS/STAT ${ }^{\circledR}$ User's Guide: Statistics Ver. 6.04, $4^{\text {th }}$ ed. SAS Institute Inc., Cary, NC.

Schiavone, A.; K. Guo; S. Tassone; L. Gasco; V. Malfatto and I. Zoccarato (2007). Use of natural extract of chestnut (Silvafeed ENC®) in broiler feeding: effect on growth performance. Ital. J. Anim. Sci., 6: 731-733.

Schiavone, A.; K. J. Guo; S. Tassone; L. Gasco; E. Hernandez; R. Denti and I. Zoccarato (2008). Effects of a natural extract of chestnut wood on digestibility, performance traits, and nitrogen balance of broiler chicks. Poult. Sci., 87: 521-527.

Schumann, B.E.; E.J. Squires and S. Leeson (2000). Effect of dietary flaxseed, flax oil and n-3 fatty acid supplement on hepatic and plasma characteristics relevant to fatty liver haemorrhagic syndrome in laying hens. British Poult. Sci., 41: 465-472.

Scislowski, V.; D. Bauchart; D. Gruffat; P. M. Laplaud and D. Durand (2005). Effects of dietary n-6 or n3 polyunsaturated fatty acids protected or not against ruminal hydrogenation on plasma lipids and their susceptibility to peroxidation in fattening steers. J. of Anim. Sci., 83: 2162-2174.

Sijben J. W.; J. W. Schrama; M. G. Nieuwland; R. Hovenier; A. C. Beynen and M. W. Verstegen (2002). Interactions of dietary polyunsaturated fatty acids and vitamin $\mathrm{E}$ with regard to vitamin $\mathrm{E}$ status, fat composition and antibody responsiveness in layer hens. Br. Poult. Sci., 432: 297-305.

Singh, H.; S. Sodhi and R. Kaur (2006). Effects of dietary supplements of selenium, vitamin E or combinations of the two on antibody response of broilers. Br. Poult. Sci., 47: 714-719.

Starcevic Kristina; Luka Krstulovic; Diana Brozic; Maja Mauric; Zvonko Stojevic; Zeljko Mikulec; Miroslav Bajic and Tomislav Masekc (2014). Production performance, meat composition and oxidative susceptibility in broiler chicken fed with different phenolic compounds. J. Sci. Food Agric., 95: 1172-1178.

Surai, P. F., and N. H. C. Sparks (2000). Tissue-specific fatty acid and $\alpha$-tocopherol profiles in male chickens depending on dietary tuna oil and vitamin E provision. Poult. Sci., 79: 1132-1142.

Tabacco, E.; G. Borreani; G. M. Crovetto; G. Galassi; D. Colombo and L. Cavallarin (2006). Effect of chestnut tannin on fermentation quality, proteolysis and protein rumen degradability of alfalfa silage. J. Dairy Sci. 89: 4736-4746.

Tietz, N.W., (1995). ed. clinical guide to laboratory tests, $3^{\text {rd }}$ ed. W.B. saunders company: 130pp.

Tobarek, M.; Y.W. Lee; R. Garrido; S. Kaiser and B. Henning (2002). Unsaturated fatty acids selectively induce an inflammatory environment in human endothelial cells. Amer. J. Clin. Nut. 75: 119-125.

Velasco, S.; L.T. Ortiz; C. Alzueta; A. Rebole; J. Trevino and M.L. Rodriguez (2010). Effect of inulin supplementation and dietary fat source on performance, blood serum metabolites, liver lipids, abdominal fat deposition, and tissue fatty acid composition in broiler chickens. Poult. Sci., 89: 16511662.

Viveros, A.; L.T. Ortiz; M.L. Rodriguez; A. Rebole; C. Alzueta; I.Arija; C. Centeno and A. Brenes (2009). Interaction of dietary high-oleic acid sunflower hulls and different fat sources in broiler chickens. Poult. Sci., 88: 141-151.

Wall, R.; R. P. Ross; G. F. Fitzgerald and C. Stanton (2010). Fatty acids from fish: the anti-inflammatory potential of long-chain omega-3 fatty acids. Nutr. Rev., 68: 280-289. 
Wang, M.L.; X. Suo; J.H. Gu; W.W. Zhang; Q. Fang and X. Wang (2008). Influence of grape seed proanthocyanidin extract in broiler chickens: effect on chicken coccidiosis and antioxidant status. Poult. Sci., 87: 2273-2280.

Zelenka, J.; D. Schneiderova and E. Mrkvicova (2006). Linseed oils with different fatty acid patterns in the diet of broiler chickens. Czech J. Anim. Sci., 51: 117-121.

\title{
تأثير إضافة الاحماض الدهنية غير المشبعة ومضادات الاكسدة للعليقة على الأداء الإتتاجي والاستجابة المناعية
} ومقاييس الدم لبداري التسمين

\author{
محمد شافعي الشرقاوى1، إبراهيم الوردانى، سيد أحمد عبد الفتاح²، ليلى دسوقي عبد السميع1 و نفيسة أحمد عبد العظيم1 \\ اقسم الإتتاج الحيواني - المركز القومي للبحوث - الدقى - الجيزة - مصر. \\ 2 قسم انتاج الدواجن ـ كلية الزراعة ـ جامعة عين شعس - شبرا الخيمة ـ القليوبيةـ مصر.
}

استهدف البحث دراسة تأثير إضافة زيت بذور الكتان أو زيت السمك بالإضافة الى مضادات الاكسدة او بدون مضادات اكسدة للعليقة

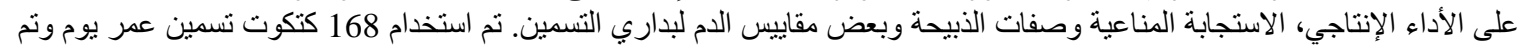

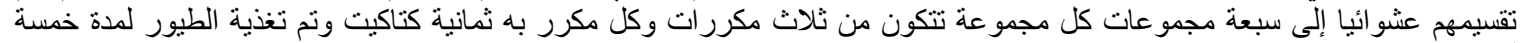

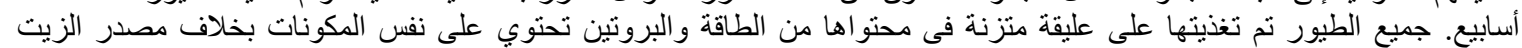

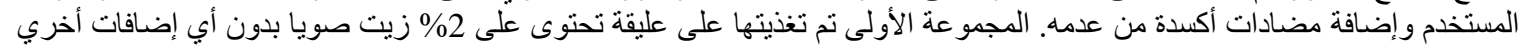

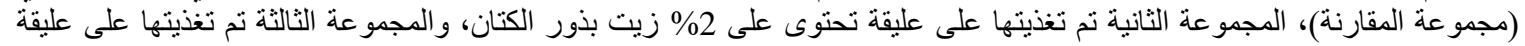

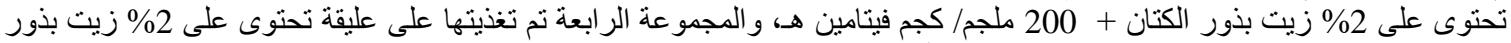

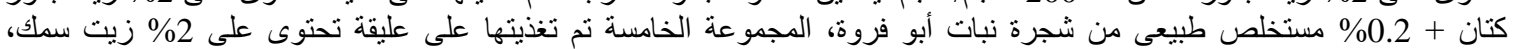

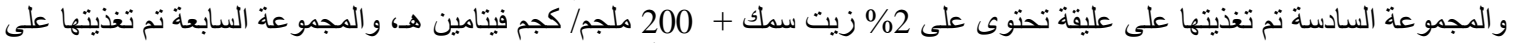

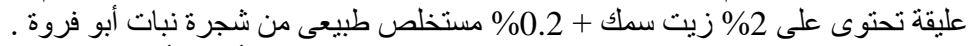

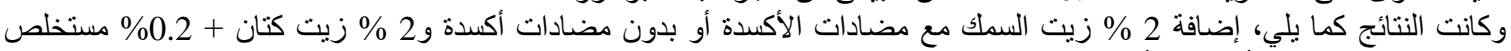

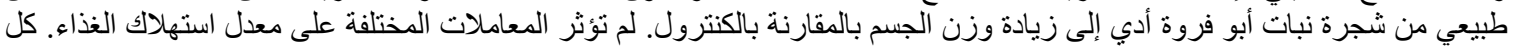

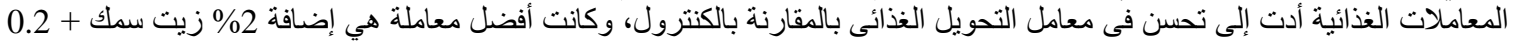

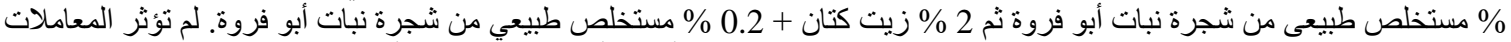

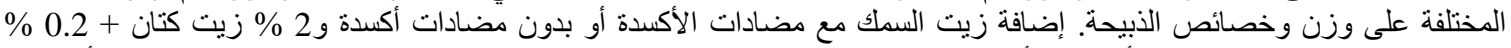

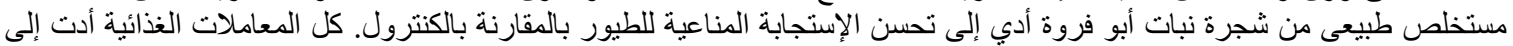

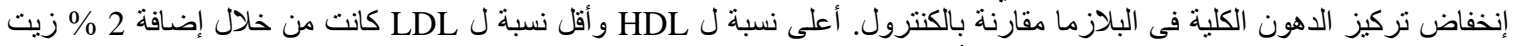

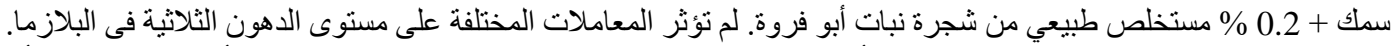

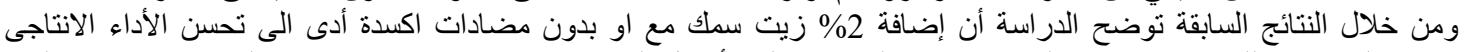

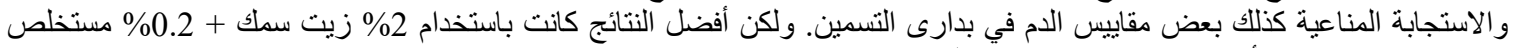
طبيعى من شجرة نبات أبو فروة في علائق بدارى التسمين. 